\title{
The Role of Islamic Microfinance Institution in Empowering Indonesian Fishing Communities
}

\author{
Azhar Alam ${ }^{1, *}$, Renaldi Sahrul Nizam ${ }^{1}$, Muhamad Taufik Hidayat ${ }^{2}$ \\ ${ }^{1}$ Department of Islamic Law and Economy, Universitas Muhammadiyah Surakarta, Surakarta, Indonesia \\ ${ }^{2}$ Department of Elementary School Teacher Education, Universitas Muhammadiyah Surakarta, Surakarta, Indonesia
}

Received December 31, 2020; Revised March 18, 2021; Accepted March 28, 2021

\begin{abstract}
Cite This Paper in the following Citation Styles
(a): [1] Azhar Alam, Renaldi Sahrul Nizam, Muhamad Taufik Hidayat, "The Role of Islamic Microfinance Institution in Empowering Indonesian Fishing Communities," Universal Journal of Accounting and Finance, Vol. 9, No. 2, pp. 178 183, 2021. DOI: 10.13189/ujaf.2021.090205.
\end{abstract}

(b): Azhar Alam, Renaldi Sahrul Nizam, Muhamad Taufik Hidayat (2021). The Role of Islamic Microfinance Institution in Empowering Indonesian Fishing Communities. Universal Journal of Accounting and Finance, 9(2), 178 - 183. DOI: 10.13189/ujaf.2021.090205.

Copyright $\odot 2021$ by authors, all rights reserved. Authors agree that this article remains permanently open access under the terms of the Creative Commons Attribution License 4.0 International License

\begin{abstract}
There are still many fishing communities in Indonesia that live in poverty. That situation happens because they have been depending on moneylenders who provide high-interest rates. This study's focuses were: First, to reveal the role of Baitul Maal wa Tamwil (BMT) or Islamic Microfinance Institution (IMFI), which embrace fishermen by implementing the free late interest system. Second, to reveal the products of IMFI for the fishing community as a form of empowerment. This study was a descriptive qualitative with a case study method. Informants of this study consist of employees and clients of BMT Mandiri Sejahtera Jawa Timur in Blimbing (BMSB), Lamongan, Indonesia. Data collection techniques used were interview, observation, and documentation. The data analysis technique was interactive analysis consisting of data reduction, data presentation, and concluding. This study showed that: First, BMSB had a pretty good role, but not effective yet in empowering fishing communities. Second, BMSB only offered savings and mortgage financing products with Islamic principles. Third, BMSB did not foster a productive attitude toward fishermen in providing additional income.
\end{abstract}

Keywords Islamic Microfinance Institution, Empowerment, Fishermen

\section{Introduction}

The role of Islamic financial institutions in Indonesia still does not reach grassroots communities. Other institutions are needed as an extension of Islamic financial institutions [1]. IMFI can answer these challenges and provide solutions to develop the grassroots economy. IMFI can improve grassroots economic activities by encouraging saving and supporting other economic activities [2].

IMFI is a microfinance institution with the concept of sharia (Islamic principles). IMFI commit themselves as recipients of funds (maal) and management of funds (tamwil) in one institutional activity. The concept of maal emerged and became part of the lives of Muslim communities in collecting and distributing funds. Whereas, in tamwil concept appears for purely productive business activities in gaining profits with the middle to lower sectors of society. The emergence of IMFI is to absorb the Muslim community's hopes and objectives amid economic anxiety based on interest. IMFI also supports funding to develop small and medium enterprises activities [3].

Indonesia as a maritime country makes the fisheries sector play an important role in the national economy. Indonesia's marine resources play an important role and have a great opportunity to increase national economic growth [4]. The Indonesian ocean region has a large and diverse marine economic potential. It creates a large fishing population in Indonesia [5].

Geographically, fishing communities live, grow, and develop in coastal areas, a transitional area between land and sea [6]. Fishermen in developing countries generally live in poverty with very minimal levels of welfare. The welfare of fishermen is very low and identical to poverty 
[7].

One of the obstacles for fishing communities to develop is their habit of relying on nature [8]. Fisherman characteristics are identical with weak capital structure, lack of market access, and low knowledge of science and technology. In such a position, fishermen's poverty becomes more complex and multidimensional [9].

The fishing community has uncertain income from their sailing activities. Income from fishing is relatively lower than their daily expenses [10]. The common problems faced by the fishing community are a capital issue as well as unfriendly season. Many fishermen try to depend on moneylenders who make their problems worse [11].

A microfinance institution is one of the solutions to reduce poverty. However, it becomes an irony when microfinance institutions provide high-interest rates to the community [12]. In contrast, IMFI provides Islamic principles as the operational basis in providing solutions for fishing communities. IMFIs do not provide interest or penalties for those who can not pay their loan yet.

To understand IMFI, one needs to understand their basic principles. Four principles are derived from Islamic law to form the core of Islamic finance. The first principle is the prohibition of interest or "riba" in Arabic terms. The second principle is risk-sharing, which means that lenders share in the business's profits and losses. The third principle is about policies in using productive funds and not solely for the consumptive need. The fourth principle is a transaction that is free from cheating, fraud, and non-transparent practices [13].

When the essence of business is established within the scope of sharia, IMFI is expected to achieve the goals of Islamic economic goals [14]. The goal of Islamic economics is to ensure that wealth circulates fairly for all groups. Islamic economics also creates a balanced life between physical and mental, material and spiritual, individual and social, and present and future [15].

Microfinance-related studies have been conducted several times. Fenton, Paavola, and Tallontire [16] focused on microfinance's role in the adaptation of household life. Mersland, Nyarko, and Szafarz [17] analyzed the mission of the microfinance organization. Problems faced by fishing communities were studied by Wekke and Cahaya [18] and Sakai [9]. However, no study focuses on the role of the Islamic Microfinance Institution in empowering fishing communities.

This study was more focused on revealing the role of IMFI in empowering fishing communities and what products are provided.

\section{Literature Review}

Sakai [19] revealed that IMFI products can provide participation for women to be able to achieve economic independence. On the other hand, the main challenge of
IMFI is to provide independence to oppressed small-scale traders from greedy capitalists.

Fianto, Maulida, and Laila [20] explained that conventional financing products with Islamic financial institutions are very different. Islamic financial institutions share advantages and disadvantages in every business transaction. IMFI has advantages over other financial institutions because it operates in line with Islamic principles and can mostly reach the poor society in rural areas.

Huda [21] revealed that one of the obstacles faced by micro-businesses was financial problems. Islamic banks can provide solutions to this problem by using financing products. These financing products include cooperation products with a profit-sharing system (musyarakah) and cooperative financing products with a profit-sharing system (mudharabah).

The poor societies were always concerned by IMFI. IMFI was always willing to help the poor who are less fortunate in improving their economic quality. IMFI provided certain products and empowerment for the poor. IMFI plays a role in the capital and provides infrastructure and training for the poor [22], [23].

Hassan [24] revealed that a microfinance system with Islamic principles provides a better welfare level for the poor. He explained several opportunities through innovative approaches for the poor by using products that comply with Islamic principles.

Mersland, Nyarko, and Szafarz [17] found three social missions of Microfinance Organization (MFO) in previous studies, including micro poverty alleviation, women's empowerment, and rural financial inclusion. However, not all MFO claim to focus on empowering women, local communities, even on poverty alleviation.

Studies proved that fishermen's poverty is getting worse with consumptive behavior that has become a culture. Fishermen's problems become more complex and multidimensional when they always depend on the season and the debt wrapping. The economic condition of fishermen has become weaker due to a lack of attention from social institutions such as microfinance institutions [9], [18], [25].

Wantah [11] with some of his surveys revealed that fishing communities do not understand good and proper financial management. They also need better knowledge in processing fish products, fostering an entrepreneurial spirit, and financial freedom.

In contrast to some previous studies, the authors have sought to focus on the role of IMFI in empowering fishing communities and what products IMFI provides to reach that goal.

\section{Method}

\subsection{Type of Study}

This study was a field study whose objects are related to 
events and symptoms in community groups. This study can also be called a case study with a qualitative descriptive approach. A qualitative study is a study that is done naturally, directly to the data source, and the authors (researchers) become instruments [26]. The objectives .of qualitative study are described and reveal as well as describe and explain [27].

\subsection{Nature of Study}

This study used a descriptive study. The data was obtained, collected, and manifested in the form of descriptions of the conditions that exist in the field. The data provided clarity about the problems.

\subsection{Data Source}

In this study, the main informants were employees and fishermen clients of BSMB, Lamongan, Indonesia. Three employees and twelve fishermen clients were recruited. All informants are males.

\subsection{Data Collecting}

This study used several methods, including (a) Interview, which is the process of getting information from informants through conversation [28]. (b) Documentation, the document is silent evidence that contains the text and images that have been taken without the intervention of researchers [29]. (c) Observation, observation activities regarding social phenomena [30].

In this study, the authors chose BSMB as the main informants. The authors deal directly with the head of BSMB and two employees. They know how to process and operate BSMB. The other informants were the fishermen clients of BSMB. They shared the results after becoming members of BSMB.

The authors conducted the interview stage after getting confirmation from BSMB (informed consent). The authors gave the purpose of the study and several questions to obtain the data. In the next stage, the authors requested permission from BSMB to participate and chose the fishermen's clients as informants. At this stage, the authors and the employees came directly to the fish auction place (Tempat Pelelengan Ikan or TPI) which is the center of fishing community activities.

\subsection{Data Validation and Analysis}

Several methods were adopted to enhance validity, including triangulation of researchers, methods, and resources [27] and respondent verification [21]. In the analysis stage, the authors used an interactive data analysis method. Interactive data analysis consists of data collection, data reduction, data presentation, and conclusion drawing. Data collection is an integral part of data analysis activities. In data reduction, the authors concluded the data, then sorted out the data in certain concept units, certain categories, and certain themes. The results of data reduction were processed in such a way so that the figure was seen more fully (in the form of sketches, synopsis, and matrixes). It is essential to facilitate the presentation and confirmation of conclusions. This process required continuous interaction [31].

\section{Results}

After several informant selection stages, the authors received three employees and twelve clients of BSMB as informants (see Table 1 and Table 2).

Table 1. List of Employee Informants

\begin{tabular}{ccc}
\hline Number & Initial & Role \\
\hline 1 & MHPR & Head of Branch \\
2 & LNHD & Teller \\
3 & MAST & Account Officer \\
\hline
\end{tabular}

Table 2. List of Client (Fishermen) Informants

\begin{tabular}{cccc}
\hline Number & Informant & Profession & Village \\
\hline 1 & WHY & $\begin{array}{c}\text { Skipper (Fisherman } \\
\text { Owner) Ship }\end{array}$ & Brondong \\
2 & BHRL & $\begin{array}{c}\text { Labor Fishermen } \\
3\end{array}$ & Blimbing \\
4 & ALM & Fisherman Skipper & Brondong \\
5 & PRS & Labor Fishermen & Brondong \\
6 & MST & Labor Fishermen & Blimbing \\
7 & MRN & Labor Fishermen & Blimbing \\
8 & MZN & Labor Fishermen & Brondong \\
9 & FRZ & Labor Fishermen & Brondong \\
10 & MKHR & Labor Fishermen & Blimbing \\
11 & ANG & Labor Fishermen & Blimbing \\
12 & WWN & Labor Fishermen & Brondong \\
\hline
\end{tabular}

Table 3. BSMB products of Clients

\begin{tabular}{ccc}
\hline Number & Product & Total \\
\hline 1 & $\begin{array}{c}\text { Mortgage Financing } \\
\text { (Rahn) and savings }\end{array}$ & 2 \\
2 & Savings & 9 \\
3 & Services & 1 \\
& TOTAL & $\mathbf{1 2}$ \\
\hline
\end{tabular}

\subsection{BSMB Products in Fishermen Community Empowerment}

From the result of interviews, documentation, and observations, the authors analyzed what products were provided by BSMB in empowering the fishing community.

From Table 3, it can be seen that there were 2 informants utilized mortgage financing product and savings product, 9 
informants in savings products, and 1 informant in service products. In Table 3 it can be seen that 12 informants are more dominant using savings products. They claim to use savings to keep watch when fishermen experience difficult times, such as things caused by natural factors, namely high rainfall with less fish production than usual.

However, an informant was using a money transfer service. BSMB employees always carried a mini transfer machine to facilitate clients using the service. The transfer service charge was IDR. 5,000.

Table 4. List of Mortgage (Rahn) Users

\begin{tabular}{|c|c|c|c|}
\hline Informant & Necessity & Submission & Guarantee \\
\hline WHY & $\begin{array}{l}\text { Ships and } \\
\text { Fishing } \\
\text { Equipment }\end{array}$ & $\begin{array}{c}\text { IDR. } \\
100,000,000\end{array}$ & $\begin{array}{c}\text { Transition } \\
\text { vehicle owner's } \\
\text { book and house } \\
\text { certificate }\end{array}$ \\
\hline BHR & School fee & $\begin{array}{c}\text { IDR. } \\
5,000,000\end{array}$ & $\begin{array}{c}\text { Transition } \\
\text { vehicle owner's } \\
\text { book and } \\
\text { marriage } \\
\text { certificate }\end{array}$ \\
\hline
\end{tabular}

Table 4 illustrates the details of necessity, amount of money, and guarantee items. BSMB also advised fishermen who applied for financing to applying saving products. Savings can be used during a lean season. BSMB can also take savings deposits to pay off the financing submission they had proposed.

\subsection{The Role of BSMB in Empowering Fishing Communities}

BSMB plays a role by providing capital loans to fishermen to meet their fishing and living costs by mortgage financing. The clients offer guarantees for what is given to the financing members. On the other hand, BSMB also plays a role in inviting people to save money for difficult times.

In terms of technical perspective, BSMB provides a form of mortgage financing to continue fishing sailing activities. Mortgage financing is given to fishermen from a technical perspective and to fishermen who need funds to pay for children's school needs.

In terms of nature, BSMB provides savings products for fishing communities. These savings products are provided for fishing communities for difficult times, such as during a famine season. During famine season, fishing communities cannot go sailing due to natural factors. In this case, fishing communities can have the capital to fulfill their daily needs when they are not working. Savings products are the most dominant products for fishing communities.

WHY stated that BSMB mortgage financing was beneficial. The guarantee was not extensive. BSMB focuses on the qualification of the enterprise than the guarantee. He also felt the fulfillment of capital and increasing the income.

Funding is also provided to the fishing community for survival. Informant BHRL applying for mortgage financing for children's school fees. He claimed that his income as a labor fisherman is still minimal. With the loans, BHRL found it helpful to face times like the famine season.

BSMB employees also present solutions for those who often have difficulty in returning the loans. BSMB advises clients to provide particular piggy banks. The piggy bank can be filled by the ability of the financing member despite only IDR. 500-1,000. These activities are carried out routinely until they can cover the financing installments.

The most dominant role given by BSMB in empowering the fishing community is by inviting the fishing community to think ahead through savings products. Fishing communities (especially labor fishermen) are low-income fishermen compared to skipper fishermen.

BSMB also participates in improving religious and social welfare by distributing zakat, infaq, sadaqah (charity funds) for orphans. With the existence of BSMB, it gives impetus to the benefit, religious and social welfare for the fishermen economy.

\section{Discussion}

Micro Finance Institutions across the country have different kinds of models of delivery as follows (1) Self Help Groups (2) Individual Banking Programs (3) Grameen Model, and (4) Mixed Model. BSMB relatively follows Individual Banking Program [32]. In terms of the Islamic economy, BSMB has implemented provisions under Islamic principles. For example, mortgage financing is not subject to fines when they exceed the due date of return. BSMB gets wages for the maintenance of the guarantee. This is under the decision of the Indonesian Ulema Council (MUI) on mortgage financing [33], as well as in line with a study by Fianto [34].

This study answers the problems faced by the fishing community as in some previous studies [11], [25] by using savings and financing products. There are some problems [11] that also cannot be fully answered by this research, where IMFI only provides what members need without giving a form of productivity and independence towards members. IMFI should be able to play a role in encouraging the fishing community (especially fishing laborers) to foster entrepreneurial spirit or work productively apart from fish production. Labor fishermen only rely on sea products and savings products without working productively during the lean season.

Different solutions for fishermen's poverty are also found in some studies [9], [18]. In those studies, the solution was chosen by the fishing community when facing poverty. Fishermen have their strategies in survival against poverty, where they prefer to help one another, promoting the principle of kinship with other fishing communities. The economic condition of fishermen has become weaker due to a lack of attention from social institutions such as cooperatives or microfinance institutions. In contrast to the 
finding of this study, the solution to the fishing community in overcoming poverty is to utilize IMFI. Explanation of the differences in the results of this study stems from the lack of knowledge of fishermen about the benefits of financial institutions in helping the improvement and welfare of the community.

This study similarity is found in several previous studies [22], [23], [34]. Those studies revealed that IMFI is always willing to help poor people who are less fortunate in improving the quality of its economy. IMFI are very beneficial for the poor because of the kind of care that has become the basis of the goals of IMFI. IMFI also provides certain empowerment to the poor through its products. However, BSMB does not provide training for fishing communities and only guides the form of communication to fishing communities.

Finally, According to [35], BSMB should do five activities to improve its performance. First, doing outreach to ensure many clients are active. Second, measuring the level of poverty accurately. Third, collecting its loan well and measure the current recovery rate (CRR) to display the repayment performance. Fourth, measuring the return produced for its owners, and return on assets (ROA). Last one, controlling its administrative costs.

\section{Conclusions}

The empowerment carried out by BSMB are (1) Meeting the capital needs and living needs of fishermen with mortgage financing products, (2) Suppressing the consumptive nature of fishing communities (especially labor fishermen) with savings products, (3) Pressing space moneylender motion in the local and outside the community, and (4) Improving religious and social welfare.

\section{Acknowledgments}

The author would like to thank you for the time given by BSMB in the data collection process.

\section{REFERENCES}

[1] Sofhiyan, "Baitul Maal Wa Tamwil (BMT) Berbasis Kearifan Lokal Gorontalo [Baitul Maal Wa Tamwil (BMT) Based on Gorontalo Local Wisdom]," Al-ulum, vol. 17, no. 1, p. $167,2017$.

[2] N. Huda, P. Putra, Novarini, and Y. Mardoni, "Baitul Maal Wa Tamwil Sebuah Tinjauan Teoritis [Baitul Maal Wa Tamwil A Theoretical Review]," Jakarta: Amzah, 2016, p. 35 .

[3] N. Dewi, "Regulasi Keberadaan Baitul Maal Wat Tamwil (Bmt) Dalam Sistem Perekonomian Di Indonesia
[Regulation of the Existence of Baitul Maal Wat Tamwil (Bmt) in the Economic System in Indonesia]," Serambi Huk., vol. 11, no. 01, p. 97, 2017.

[4] B. Resosudarmo and D. Hartono, "Analisa Penentu Sektor Prioritas di Kelautan dan Perikanan Indonesia [Analysis of Priority Sector Determinants in Indonesian Maritime Affairs and Fisheries]," Pesisir dan Lautan, vol. 4, no. 3, p. 6, 2017.

[5] E. Retnowati, "Nelayan Indonesia Dalam Pusaran Kemiskinan Struktural," Perspektif, vol. XVI, no. 3, p. 150, 2011.

[6] H. Hamdani and K. Wulandari, "( The Factor Of Poverty Causes Traditional Fisherman )," Artik. Ilm. Has. Penelit. Mhs., vol. 1, p. 2, 2013.

[7] A. Irwansyah Fauzi, "Kondisi Nelayan Indonesia GD5203 Integrasi Sains dan Teknologi Dalam Perspektif Pembangunan Wilayah Pesisir, Laut, dan Maritim [Condition of Indonesian Fishermen GD5203 Integration of Science and Technology in the Perspective of Coastal, Marine, and Marit," p. 2, 2018.

[8] P. F. Bueno and A. Schiavetti, "The influence of fisherman scale in the resilience of socio-ecological systems: An analysis using Q methodology," Ocean Coast. Manag., vol. 169, no. October 2018, pp. 214-224, 2019, doi: 10.1016/j.ocecoaman.2018.12.008.

[9] A. Cahaya, "Fishermen Community in the Coastal Area: A Note from Indonesian Poor Family," Procedia Econ. Financ., vol. 26, no. 15, pp. 29-33, 2015, doi: $10.1016 / \mathrm{s} 2212-5671(15) 00801-1$.

[10] M. Rani, "Insurance Protection For Fisherman," Selat, p. 2, 2016.

[11]E. Wantah, "Pemberdayaan Nelayan Berbasis Pendidikan Ekonomi Dan Potensi Pesisir di Kabupaten Minahasa Utara [Fishermen Empowerment Based on Economic Education and Coastal Potential in North Minahasa District]," J. Teor. dan Praksis Pembelajaran IPS, vol. 2, no. 2, p. 50, 2017, doi: 10.17977/um022v2i22017p095.

[12] I. Widiarto and A. Emrouznejad, "Social and financial efficiency of Islamic microfinance institutions: A Data Envelopment Analysis application," Socioecon. Plann. Sci., vol. 50, pp. 1-17, 2015, doi: 10.1016/j.seps.2014.12.001.

[13] M. El-Komi and R. Croson, "Experiments in Islamic microfinance," J. Econ. Behav. Organ., vol. 95, pp. 252-269, 2013, doi: 10.1016/j.jebo.2012.08.009.

[14] S. K. A. Manan and M. H. B. M. Shafiai, "Risk Management of Islamic Microfinance (IMF) Product by Financial Institutions in Malaysia," Procedia Econ. Financ., vol. 31, no. 15 , pp. 83-90, 2015, doi: 10.1016/s2212-5671(15)01134 $-\mathrm{X}$.

[15] Mursal and Suhadi, "Implementasi Prinsip Islam dalam Aktivitas Ekonomi [ Implementation of Islamic Principles in Economic Activities]," vol. 9, no. 1, p. 67, 2015.

[16]A. Fenton, J. Paavola, and A. Tallontire, "The Role of Microfinance in Household Livelihood Adaptation in Satkhira District, Southwest Bangladesh," World Dev., vol. 92, pp. 192-202, 2017, doi: 10.1016/j.worlddev.2016.12.00 4.

[17] R. Mersland, S. A. Nyarko, and A. Szafarz, "Do social 
enterprises walk the talk? Assessing microfinance performances with mission statements," J. Bus. Ventur. Insights, vol. 11, no. February, p. e00117, 2019, doi: 10.1016/j.jbvi.2019.e00117.

[18] I. S. Wekke and A. Cahaya, "Fishermen Poverty and Survival Strategy: Research on Poor Households in Bone Indonesia," Procedia Econ. Financ., vol. 26, no. 15, pp. 7-11, 2015, doi: 10.1016/s2212-5671(15)00962-4.

[19] M. Sakai, “Growing together in partnership: Women's views of the business practices of an Islamic Savings and Credit Cooperative (Baitul Maal wat Tamwil) in Central Java, Indonesia," Womens. Stud. Int. Forum, vol. 33, no. 4, pp. 412-421, 2010, doi: 10.1016/j.wsif.2010.02.015.

[20]B. A. Fianto, C. Gan, B. Hu, and J. Roudaki, "Equity financing and debt-based financing: Evidence from Islamic microfinance institutions in Indonesia," Pacific Basin Financ $J$, vol. 52, no. August 2016, pp. 163-172, 2018, doi: 10.1016/j.pacfin.2017.09.010.

[21] A. N. Huda, "The Development of Islamic Financing Scheme for SMEs in a Developing Country: The Indonesian Case," Procedia - Soc. Behav. Sci., vol. 52, pp. 179-186, 2012, doi: 10.1016/j.sbspro.2012.09.454.

[22] L. Tamanni and M. H. Azrin Haji Besar, "Profitability vs Poverty alleviation: has banking logic influences Islamic microfinance institutions ?," vol. 4, no. 2, pp. 260-279, 2019, doi: 10.1108/AJAR-05-2019-0039.

[23]P. Wulandari and S. Kassim, "Issues and challenges in financing the poor: case of Baitul Maal Wa Tamwil in Indonesia,” 2016, doi: 10.1108/IJBM-01-2015-0007.

[24] A. Hassan, "Financial Inclusion of The Poor: From Microedit to Islamic Microfinancial Services," Humanomics, vol. 31, no. 3, p. 364, 2015.

[25] I. Shimpei and R. Shaw, Integrated Lagoon Fisheries Management: Resource Dynamics and Adaptation Article information:, vol. 3. Elsevier, 2015.
[26] S. Hadi, "Pemeriksaan Keabsahan Data Penelitian Kualitatif Pada Skripsi [Examination of the Validity of Qualitative Research Data on Thesis]," Ilmu Pendidik., vol. 22, no. 1, 2016.

[27]B. S. Bachri, "Meyakinkan Validitas Data Melalui Triangulasi Pada Penelitian Kualitatif [Ensuring Data Validity Through Triangulation in Qualitative Research]," Teknol. Pendidik., vol. 10, pp. 46-62, 2010.

[28] S. Q. Qu and J. Dumay, "The qualitative research interview," Qual. Res. Account. Manag., vol. 8, no. 3, pp. 238-264, 2011, doi: 10.1108/11766091111162070.

[29] G. A. Bowen, "Document Analysis as a Qualitative Research Method," Qual. Res., vol. 9, 2009, doi: 10.3316/QRJ0902027.

[30] G. S. Gemilang, "Metode Penelitian Kualitatif dalam Bidang Bimbingan dan Konseling [Qualitative Research Methods in the Field of Guidance and Counseling]," Fokus Konseling, vol. 2, no. 2, 2016, [Online]. Available: http://ejournal.stkip mpringsewu-lpg.ac.id/index.php/fokus/a.

[31]A. Rijali, "Analisis Data Kualitatif [Qualitative Data Analysis]," Alhadharah, vol. 17, no. 33, pp. 81-95, 2018.

[32] M. Singh, "Status of Microfinance in India - A Review," in 10th International Conference on Recent Development in Engineering Science, Humanities, and Management, 2017, pp. 32-44, [Online]. Available: http://data.conferenceworld. in $/ \mathrm{ICSSR} / 5$.pdf.

[33] National Sharia Board-Indonesia Council of Ulama, Rahn. Indonesia, 2002, p. 3.

[34] B. A. Fianto, H. Maulida, and N. Laila, "Determining factors of non-performing financing in Islamic microfinance institutions," Heliyon, vol. 5, no. 8, 2019, doi: 10.1016/j.heliyon.2019.e02301.

[35] C. N.K, Readings in Lifelong Learning. New Delhi: Department of Adult, Continuing Education and Extension, University of Delhi, 2009. 